\title{
GLOBOS ĮSTAIGOSE IR BIOLOGINĖSE ŠEIMOSE AUGANČIUU VAIKŲ AKTYVAUS LAISVALAIKIO VEIKLOS
}

\author{
Diana Rèklaitienė, Jūratė Požerienė, Vida Ostasevičienė, Aida Gaižauskienė
}

Lietuvos kūno kultūros akademija, Kaunas, Lietuva

\begin{abstract}
Diana Rèklaitienė. Socialinių mokslų daktarè. Lietuvos kūno kultūros akademijos Taikomosios fizinès veiklos katedros docentè, Rekreacijos, turizmo ir sporto vadybos katedros vedẻja. Mokslinių tyrimų kryptys: specialiujų poreikių ir kitų socialiai jautrių asmenų grupių gyvenimo kokybė; rekreacinè veikla, kaip asmens saviugdos ir savirealizacijos veiksnys.
\end{abstract}

\section{SANTRAUKA}

Laisvalaikis yra socialine erdvè, kurioje baziniai santykiai gali būti stiprinami, plètojami, išreiškiami. Dèl šios priežasties laisvalaikis stipriai susijęs su tuo, kokias vertybes mes puoselejjame, kokie yra mūsu prioritetai, ir tai labai svarbu šeimos, visuomeniniuose santykiuose. Našlaičiams ir tèvu globos netekusiems vaikams, kurie ilgai gyvena vaiku globos institucijose, tapimas savarankiškais ir suaugusiais yra dar labiau apsunkintas, todèl reikalingas nuoseklus, tęstinis vaiko poreikius ir branda atitinkantis savarankiš̌ku igüdžiu ugdymas. Pasaulyje atlikti tyrimai rodo, kad tèvu

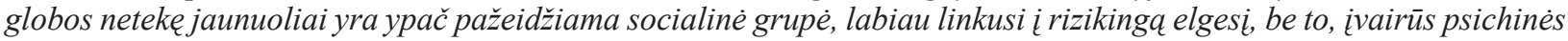
sveikatos sutrikimai šioje grupeje diagnozuojami kelis kartus dažniau. Pažymètina, kad Lietuvoje moksliniu tyrimu apie vaiku, gyvenančiu globos namuose, gyvenima iš tiesu trūksta. Nedaug tyrimu ir nagrinejjančiu vaiku globos istaigu ugdytiniu pedagogines psichologines problemas, turiningo laisvalaikio reikšmę ju ugdymui.

Tyrimo tikslas - ištirti globos istaigose ir biologinèse šeimose augančiu vaiku aktyvaus laisvalaikio veiklas. Tyrimo uždaviniai: nustatyti, kur ir kokia laisvalaikio veikla turi galimybę ir užsiima globos namuose ir biologinèse šeimose augantys vaikai; ištirti vaiku požiūri i socialiai netinkamq veikla; atlikti globos namuose ir biologinèse šeimose auganči vaiku tyrimo rezultatu lyginamaja analizę.

Naudota anketine apklausa. Tyrimo duomenys apdoroti pasitelkus SPSS-15 kompiuterine programa. Buvo apklausti 716 skirtingose globos istaigose ir 908 biologinèse šeimose augantys 12-19 metu vaikai ir 176 vaiku globos (rūpybos) sistemos ekspertai.

Išvados. Globos namuose ir biologinèse šeimose angantys vaikai turi panašiu galimybiu dalyvauti ivairiose laisvalaikio veiklose mokyklose ir kitose istaigose. Visgi kur kas aktyviau laisvalaikio veikloje dalyvauja biologinèse šeimose augantys vaikai. Nepriklausomai nuo socialinés aplinkos skirtumu danguma vaiku labiausiai mègsta sportine veikla, kiek mažiau — muzikinę, nemažai vaiku užsiima kita menine veikla. Biologinèse šeimose augantys vaikai, vertindami savo gebejjimus, kur kas dažniau nei globos namu vaikai nurodè, kad jiems geriausiai sekasi mokslai ir bendravimas. Tuo tarpu globos namu auklètiniai dažniau teigè, kad jiems gerai sekasi dainavimas. Kur kas daugiau biologinèse šeimose auganči vaiku teigè, kad moka atsispirti draugu spaudimui isitraukti i netinkamq veikla, turi savo tvirta nuomonę, apie tai žino, nors nemažai ir globos namu auklètiniu taip pat sutiko su šiuo teiginiu. Globos namuose augantys moksleiviai dažniau už šeimose augančius vaikus teigia, kad kartais atsispirti drangu spaudimui užsiimti netinkama veikla būna sunku.

Raktažodžiai: laisvalaikio veiklos, globos namai, biologinès šeimos, rizikingas elgesys.

\section{IVADAS}

$\mathrm{L}$ aisvalaikis - tai laisvas nuo būtinu užsièmimų laikas, skirtas asmeniniams poreikiams tenkinti, taip pat plèsti žinias, lavintis ir dvasiškai tobulèti. Kiekvienas žmogus turi teisę i dvi svarbiausias egzistavimo sąlygas: darbą ir laisvalaiki (Shivers, deLisle, 1997; McGill, 1996) Deja, dažnai tiek šeimose, tiek globos įstaigose augančių vaikų laisvalaikis ir būna laisvas, neorganizuotas, t. y. pasyvus ir suprantamas kaip poilsis, pasireiškiantis nieko neveikimu. Laisvalaikio praleidimo būdai kiekvieno individo asmeninè pasirinkimo teisè, kuria asmuo išreiškia savo valią, atskleidžia savo požiūrị i vertybių sistemą ir parodo bendrą vidinę kultūrą. Pagrindinis laisvalaikio uždavinys socialineje sistemoje — garantuoti tokią laiko praleidi- 
mo kokybę, kad formuotųsi kuo ịvairiapusiškesnè asmenybé, gebanti integruotis $\mathfrak{i}$ visuomenę. Apie turiningo ir aktyvaus laisvalaikio reikšmę ne tik vaikų sveikatai, bet jų socializacijai, saviraiškai, savarankiškumui, nusikalstamumo prevencijai pastaruoju metu kalbame visais lygiais visame pasaulyje (Fletcher et al., 2003; Salmon et al., 2004; Witt, Caldwell, 2005; Heath, 2009; Leonard, 2010). W. Damon (2004), S. L. Sklar ir C. E. Autry (2008) teigia, kad socialineje atskirtyje gyvenantys ar rizikos grupès vaikai ir jaunuoliai turètú būti ypač skatinami dalyvauti laisvalaikio veiklose ugdyti gebejjimus nepaisant visų aplinkybių, nes sistemingas aktyvus laisvalaikio praleidimas padeda žmonèms, kovojantiems su fiziniais, psichologiniais ar psichiniais trūkumais ir jiems atskleidžia gyvenimo kokybę, egzistencijos prasmę. Aktyvaus laisvalaikio arba sportineje veikloje dalyvaujantys vaikai igyja daugiau bendravimo patirties, išmoksta džiaugtis pergale ir susitaikyti su pralaimejjimu, igauna igūdžių kovoti konkurencingose situacijose, agresiją išmoksta nukreipti į sportinę veiklą ir ją paversti pozityvia. Tokia patirtis praverčia ir kasdieniame gyvenime.

Dèl nepalankių vystymosi sąlygų vaikystėje, igytos neigiamos socialinès patirties, nesusiformavusio prieraišumo jaunuoliams, palikusiems globos namus, būdinga sudètingesnè socialinè adaptacija, negebėjimas užmegzti pozityvių ir ilgalaikių ryšiu su kitais asmenimis, stabilių vidiniu paramos šaltinių stoka, konstruktyvių konfliktų sprendimo igūdžių ir streso įveikimo gebèjimu, prasta frustracijos tolerancija. Tèvų globos netekę asmenys dažnai neturi sveikos gyvensenos žinių ir igūdžių, anksti pradeda lytinį gyvenimą, dažniau nusikalsta, neturi susiformavusių teigiamų vertybinių nuostatų, jiems trūksta socialinių igūdžių, yra greičiau pažeidžiami. Visa tai galima būtų iš dalies kompensuoti sudarant galimybes vaikams atskleisti save per laisvalaikio užsièmimus (Carter et al., 2003; Stumbo, Peterson, 2004; Žalimienè, 2005; Sklar, Autry, 2008; Rèklaitiené ir kt., 2008; Leonard, 2010). Visgi daugumos globos instituciju darbo organizavimas apriboja vaiku savarankiškumo plètojimąsi, ribotos ir ju galimybès laisvai nuspręsti, kaip leisti savo laisvalaikị. Pastaruoju metu mokslinèje literatūroje vis daugiau pabrěžiama kūrybiško, individualius kiekvieno poreikius ir gebėjimus atitinkančio laisvalaikio praleidimo poveikis žmogaus savirealizacijai, jo savivartei ir tolesnès profesinès karjeros sèkmei, ir tai ypač svarbu kalbant apie globos namuose augančius vaikus (Žalimienè, 2005; Sklar, Autry, 2008).

Lietuvoje mokslinių tyrimų apie vaikų, gyvenančiu globos namuose, gyvenimą iš tiesų trūksta. Galima paminèti tik tokius tyrejus kaip J. Laužiką, M. Barkauskaitę, A. Šerkšną, N. Taurienę. Nuo $2004 \mathrm{~m}$. Lietuvoje apgintos tik dvi daktaro disertacijos (Snieškienè, 2001; Staskevičienė, 2007) apie vaiku globos įstaigas ar jų ugdytinius.

Iškèlėme problemini klausimą, ar globos isstaigose ir biologinèse šeimose augantys vaikai turi vienodas sąlygas užsiimti jiems patinkama laisvalaikio veikla?

Tyrimo tikslas - ištirti globos įstaigose ir biologinèse šeimose augančių vaikų aktyvaus laisvalaikio veiklas.

\section{TYRIMO METODIKA}

Anketinès apklausos būdu nustatyta, kur ir kokia laisvalaikio veikla turi galimybę ir užsiima globos namuose ir biologinèse šeimose augantys vaikai, ištirtas jų požiūris į socialiai netinkamą veiklą. Tyrimo metu naudotos dvi skirtingos anketos - vaikams ir ekspertams. Anketos sudarytos remiantis L. Žalimienès ir kt. (2005), D. Rèklaitienès. ir kt. (2008) LR Socialinès apsaugos ir darbo ministerijos užsakymu atliktų tyrimu metu naudotomis anketomis bei K. E. Berg ir R. W. Latin (2004) pateiktais anketos sudarymo reikalavimais.

Matematinès statistikos metodai taikyti tyrimo rezultatams apdoroti. Tyrimo duomenys apdoroti pasitelkus SPSS-15 kompiuterinę programą. Taikytas $c h i$ kvadrato $\left(\chi^{2}\right)$ kriterijus, kuriuo ivertinti skirtumai tarp dviejų imčių.

Tiriamieji. Tiriant bendras respondentu skaičius buvo 1800, iš jų: apklausoje dalyvavo ir anketas pilnai užpilde 716 skirtingose globos istaigose ir 908 biologinèse šeimose augantys 12-19 metu vaikai; apklausti 176 vaiku globos (rūpybos) sistemos ekspertai (vaikų globos namu darbuotojai, savivaldybiu vaiko teisių apsaugos tarnybų darbuotojai ir kt.) iš 19 Lietuvos globos namur.

Tyrimo organizavimas. Apklausa buvo vykdoma per 2008 metu lapkričio ir gruodžio mènesius. Tikslinèms grupèms buvo išdalytos anketos didžiuosiuose Lietuvos miestuose, rajonuose, kaimuose. Lizdinès atsitiktinès atrankos principu buvo pasirinktos vaiku globos istaigos ir bendrojo lavinimo mokyklos. Buvo vykdoma apklausa 32 globos istaigose, kuriose gyvena 2359 vaikai. 
Dauguma (75\%) tirtu globos ịstaigu auklètiniu gyveno apskrities globos namuose, $8,1 \%$ - nevyriausybiniuose, $16,9 \%$ - savivaldybès globos namuose. Bologinėse šeimose augantys vaikai buvo apklausti devyniuose skirtinguose Lietuvos miestuose.

\section{REZULTATAI}

Ekspertus apklausėme norèdami išsiaiškinti globos i̊staigoje gyvenančiu vaikų galimybę lankyti ịvairius būrelius neformaliojo švietimo ir kitose istaigose. Dauguma jų atsaké, kad vaikai turi šią galimybę. Daugiausia $(99,4 \%)$ respondentų atsakè, kad vaikai gali lankyti sporto būrelius, $96,3 \%$ - meninès raiškos būrelius, $86,5 \%$ darbinių igūdžių lavinimo būrelius, 97,7\% ekspertu atsaké, kad vaikai turi galimybę vykti i koncertus, teatrą, kiną. Kiti duomenys pateikti lentelèje.

Ekspertai nurodè, kad dažniausiai globos namuose gyvenantys vaikai turi galimybę lankyti būrelius bendrojo lavinimo mokykloje $(89,9 \%)$, sporto mokykloje $(55,1 \%)$, muzikos mokykloje (46\%), dailès mokykloje (36,9\%), moksleiviu švietimo centre $(30,1 \%)$, sporto klube $(21,6 \%)$, nevyriausybinèse organizacijose $(26,7 \%)$, kultūros namuose $(3,4 \%)$, globos institucijoje $(10,8 \%)$. $131(74,4 \%)$ ekspertas nurodè, kad ju globos istaigose taip pat organizuojami papildomo ugdymo būreliai, 36 (20,5\%) atsakè, kad organizuojami tik kai kurie būreliai, 7 ekspertai (4\%) kad istaigoje tokių būreliu nèra, $2(1,1 \%)$ i ši klausimą neatsakè.

Dauguma globos namų auklètinių teigè galị užsiimti jiems patinkama veikla, tik vyresnieji turi daugiau galimybių mokytis verslo pradmenų. Dažniausiai visi gali sportuoti, žaisti stalo žaidimus, dainuoti, mokytis žaisti ir dirbti kompiuteriu, vykti i teatrus, koncertus, kiną. Biologinejje šeimoje augantys jaunesni vaikai teigè, kad dažniausiai jie leidžia laiką su draugais, žiūri televizorių, sportuoja, būna kieme. Vyresni vaikai dažniau nei jaunesnieji leidžia laiką su draugais, rečiau sportuoja ar žiūri televizorių. Iš kitų veiklų respondentai paminèjo tokius laisvalaikio užsièmimus: „padedu šeimai“, „,einu i teatrą“, „skaitau knygas“, „domiuosi šunimis“, „darau valgyti““.

38,3\% 15-18 m. globos namuose augančiu jaunuolių ir 34,66\% 12-14 m. vaikų patinkama papildoma veikla užsiima mokykloje, kurioje mokosi, atitinkamai $7,29 \%$ ir $6,78 \%$ papildoma veikla užsiima globos namuose, $12,5 \%$ ir $11,7 \%$ moksleiviu lanko specializuotas sporto ar meno mokyklas, $42 \%$ vyresniu ir $46 \%$ jaunesniu moksleivių teigè papildoma veikla visai neužsiimantys $\left(\chi^{2}=1,267 ; p=0,260 ; d f=1\right)$. Tuo tarpu tik $22,6 \%$ jaunesnių biologinèse šeimose augančiu ir $28,3 \%$ vyresnių tiriamuju atsakè, kad neužsiima jokia papildoma veikla (skirtumai tarp grupių patikimi $-\chi^{2}=31,317 ; \mathrm{p}<0,001$; $\mathrm{df}=2$ ). $65,6 \%$ jaunesniu ir $48 \%$ vyresniu moksleiviu papildoma veikla užsiima mokyklose, likusieji atitinkamai $14 \%$ ir $24 \%$ - specialiose sporto ir meno mokyklose. Paaiškejjo, kad beveik pusei jaunesnių ir vyresnių globos namuose augančių moksleiviu labiausiai patinka sportinè veikla. Trečdalis moksleivių linkę i meninę veiklą (groja, dainuoja, šoka, vaidina) (1 pav.). Buvo ir kitokių atsakymų: „nèra čia ką veikti“, „nuobodžiauju“, „nieko nenoriu“, „nieko nedarau“, „sèdžiu savo kambaryje“, „einu ị lauką žaisti“, ,aš daugiau laiko rašau eiles".

$50,6 \%$ visų biologinèse šeimose augančiu jaunuoliu teigia, kad jie sportuoja, 34,4\% respondentu papildoma veikla yra muzika. Atsakymo

\begin{tabular}{|l|l|l|l|l|l|l|}
\hline \multirow{2}{*}{ Veiklos } & \multicolumn{2}{|c|}{ Taip } & \multicolumn{2}{c|}{ Ne } & \multicolumn{2}{c|}{ Nežinau } \\
\cline { 2 - 8 } & \% & \multicolumn{1}{|c|}{ N } & \multicolumn{1}{c|}{$\%$} & \multicolumn{1}{c|}{ N } & \multicolumn{1}{c|}{$\%$} & N \\
\hline Sporto būreliai & 99,4 & 165 & 0,6 & 1 & 0 & 0 \\
\hline Meninès raiškos būreliai & 96,3 & 157 & 3,1 & 5 & 0,6 & 1 \\
\hline Darbinių igūdžių lavinimo būreliai & 86,5 & 141 & 11 & 18 & 2,5 & 4 \\
\hline Darbo kompiuteriu kursai & 64,7 & 101 & 28,2 & 44 & 7,1 & 11 \\
\hline Verslo pradmenų mokymasis & 37,2 & 55 & 50,7 & 75 & 12,2 & 18 \\
\hline Koncertų, teatro, kino lankymas & 97,7 & 168 & 2,3 & 4 & 0 & 0 \\
\hline
\end{tabular}

Lentelé. Ekspertu atsakymo ị klausima „Ar Jūsų ịstaigoje augantys vaikai turi galimybę lankyti būrelius kitose neformaliojo švietimo istaigose" procentinis skirstinys 
1 pav. Globos namuose augančių vaiky atsakymu i klausimą ,Kokia veikla užsiimi?"“ procentinis skirstinys pagal amžių

Pastaba. $\chi^{2}=1,482 ; p=0,830 ; d f=4$

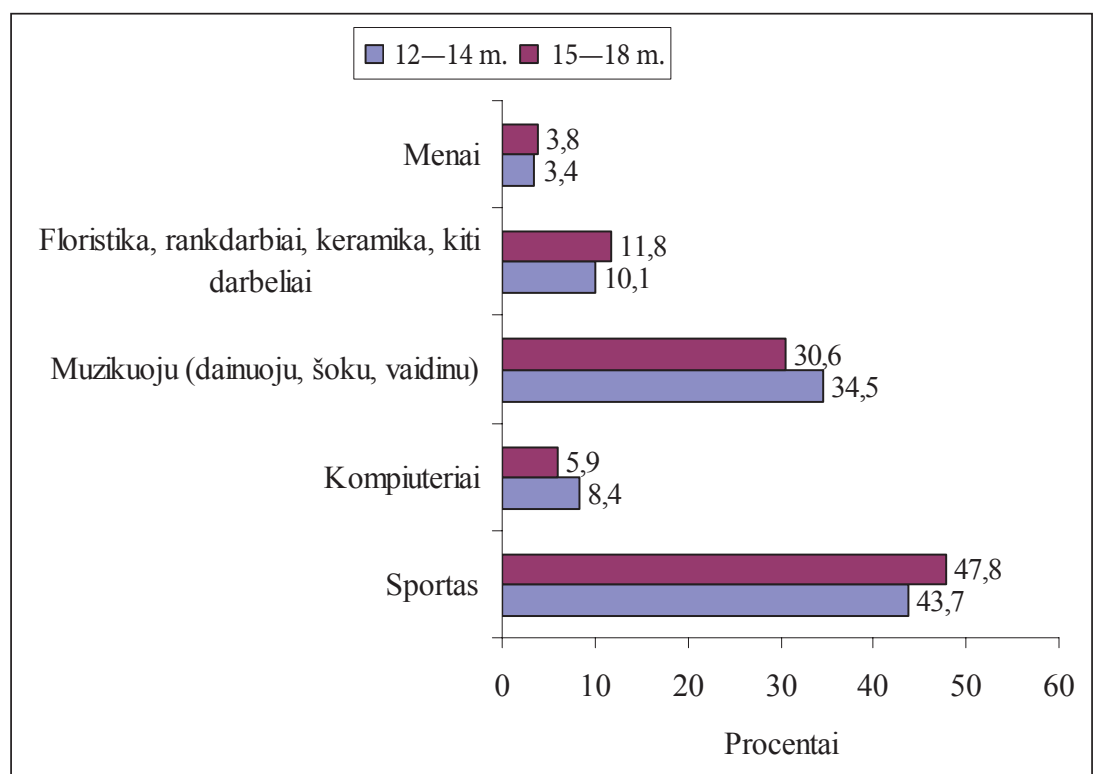

2 pav. Biologinėse šeimose augančių vaikụ atsakymų i klausimą „,Kokia veikla užsiimi?"“ procentinis skirstinys

Pastaba. $\chi^{2}=12,307 ; \mathrm{p}<0,031 ; \mathrm{df}=2$.

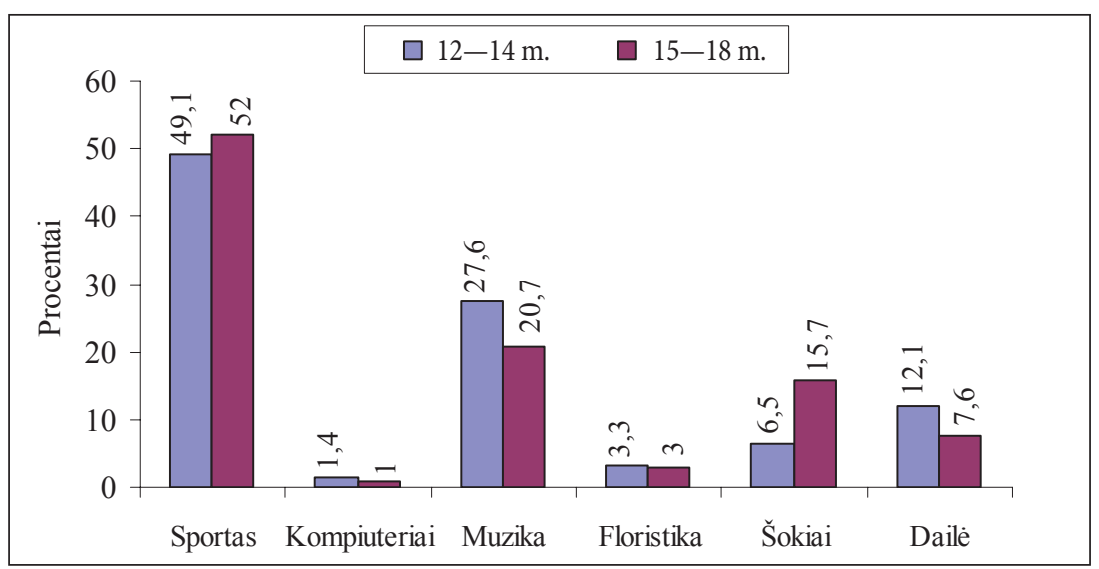

i klausimą „Kokia veikla užsiimi?“” procentinis skirstinys pagal amžių pateiktas 2 paveiksle. Matome, kad veiklos pasirinkimas yra panašus abiejose grupèse.

Sau patinkama veikla $87,5 \%$ jaunesniu ir $86,1 \%$ vyresnių globos namų auklètinių užsiima dèl to, kad ta veikla patinka. Tik pavieniai moksleiviai šią veiklą rinkosi dèl draugų, auklètojų, tèvų ar kitų priežasčių. 6,5\% vyresnių ir 7,7\% jaunesnių moksleivių teigia, kad „neturi iš ko rinktis“ $\left(\chi^{2}=3,844 ; p=0,572 ; \mathrm{df}=5\right)$. Beveik $90 \%$ visu biologinèse šeimose augančiu tiriamuju i klausimą „Kodèl pasirinkai būtent šią veiklą?“" atsakè, kad patinka. Tik nedaugelis pažymejjo kitus atsakymus. Patikimo skirtumo tarp grupių nebuvo. Tik keletas vaikų nurodè norintys užsiimti kita veikla, bet dèl ivvairių priežasčių to negali padaryti (neleidžia tèvai, trūksta pinigų).

Palyginus biologinèse šeimose ir globos namuose augančiu jaunuolių atsakymus ị klausimą „Kaip manai, kas Tau labiausiai sekasi?“, 23,5\% biologinėse šeimose augančių vaikų ir tik 13\% glo- bos namų vaikų atsakè — „mokslai“ ( $<<0,001)$, atitinkamai $19,9 \%$ vienos ir $21 \%$ kitos grupès vaiku atsakè — „sportas“, 15 ir tik 5\% — „bendrauti su žmonèmis“ ( $p<0,001), 7,2$ ir $9,5 \%$ — ,,piešimas“, 6,6 ir 16,4\% — „dainavimas“ $(p<0,001)$, 6,4 ir 4,8\% — „viskas sekasi“, 6,7 ir $11,3 \%$ atsakè, kad nežino, kas jiems geriausiai sekasi, keletas vaiku paminejjo, kad sekasi rankdarbiai ir medžio darbai.

Beveik pusè visu globos namuose augančių moksleiviu teigia, kad geba atsispirti draugu spaudimui ísitraukti i netinkamą veiklą, nes turi savo tvirtą nuomonę. Trečdalis moksleivių neprasideda su tokia kompanija, tačiau apie 18\% vyresnių ir 11\% jaunesniu moksleiviu kartais neatsispiria draugų spaudimui: vyresnieji teigia, kad su draugais reikia eiti išvien, o jaunesnieji mano, kad draugai stipresni už juos ir todèl negali pasipriešinti (3 pav.). Dauguma tiek jaunesnių, tiek vyresnių biologinèse šeimose augančių vaikų, atsakydami i klausima „Ar moki atsispirti draugu spaudimui įsitraukti i netinkamą veiklą?“, teigia: 
„taip, turiu savo tvirtą nuomonę ir kiti tai žino“" (skirtumas tarp grupiu patikimas, $\mathrm{p}<0,001$ ). Patikimai daugiau $(p<0,001)$ vyresnių nei jaunesniu moksleiviu atsakè, kad kartais atsispirti būna sunku.

Daugiau nei puse $(62,6 \%$ jaunesniu ir $66,3 \%$ vyresnių) visų globos namų auklètinių buvo bausti už vagystę, chuliganizmą, sukčiavimą, plèšimą, kūno sužalojimą ar kitus teisès pažeidimus. Atitinkamai $85,3 \%$ jaunesnių ir $74,7 \%$ vyresniu biologinèse šeimose augančiu vaikų i šį klausimą atsakè teigiamai (skirtumai tarp grupių patikimi, $\mathrm{p}<0,001)$. Atitinkamai 14,2 ir $10,9 \%$ globos namuose, 8,3 ir $6,1 \%$ biologinèse šeimose augančiu vaiku parašè — „nesakysiu“. Likusieji respondentai teige, kad nebuvo bausti (atitinkamai 23,2\% globos namu ir 22,8, 6,4 ir 19,2\% biologiniu šeimų vaikai).

Daugiau kaip pusė abieju grupių moksleiviu yra padarę nusižengimą, už kurị nebuvo nubausti. $51 \%$ jaunesnių globos namų auklètinių ir 54,1\% vyresnių, atitinkamai 61,8 ir $58,6 \%$ biologinèse šeimose augančių vaikų. 34 globos namų auklètinių sake, kad jie nèra padarę nusižengimų, už kuriuos nebūtų nubausti, o $26,9 \%$ jaunesnių ir 35,3\% vyresnių biologinėse šeimose augančiu vaikų $i$ ši klausimą atsakè teigiamai. Likusieji į šį klausimą atsakyti nenorejo.

\section{REZULTATŲ APTARIMAS}

Apibendrinant galima teigti, kad didžioji dalis apklaustų moksleivių, gyvenančių globos namuose ir biologinèse šeimose, užsiima popamokine veikla. Tyrimo duomenys byloja, kad pagal veiklos sritis daugiausia moksleiviai dalyvauja sporto ir meninès pakraipos užsièmimuose. Panašias tendencijas pastebejo ir kiti autoriai (Ignatavičius ir kt., 2003; Kaffemaniené, Tumelyté, 2008)

Tirtų moksleivių dalyvavimą ar nedalyvavimą laisvalaikio veiklose galima būtų aiškinti keliais požiūriais. Pirma, papildomos laisvalaikio veiklos organizavimu ir prieinamumu. Tyrimo duomenimis, tirtu globos įstaigu ekspertai nurodé, kad daugelis laisvalaikio veiklu yra prieinamos tiek globos istaigos viduje, tiek išorèje, t. y. sporto mokyklose, klubuose, visuomeninèse organizacijose. Taip pat pastebèta, kad dalis biologinėse šeimose augančiu vaikų laisvalaikio veiklą pasirenka pagal tėvų norus. Antra, papildomos veiklos formas lemia ir mokyklos tradicijos bei ugdymo tikslai. Tyrimo duomenys rodo, kad globos namuose ir biologinè- se šeimose augantys moksleiviai, dažniausiai dalyvauja tose laisvalaikio veiklose, kurios Lietuvoje turi gilias tradicijas (pvz., sportas, menas). Anot S. Ignatavičiaus ir bendraautorių (2003), patys pedagogai yra labiau linkę $i \mathfrak{i}$ „švarias“ papildomo ugdymo veiklas ir iš dalies ignoruoja tokias veiklas kaip pagalba socialiai remtiniems asmenims ar neigaliesiems, kitas savanoriškas veiklas. Tyrimo duomenys parodé, kad didesnè dalis vaiku, augančių biologinèse šeimose, geba atsispirti draugu spaudimui įsitraukti i netinkamą veikla, lyginant su tirtais globos namų vaikais. Šiuos duomenis patvirtina ir kiti autoriai (Fletcher et al., 2003; Salmon et al., 2004; Heath, 2009). Galima būtu daryti prielaida, kad vaikai ir paaugliai, gyvendami saugioje aplinkoje su abiem tėvais, išmoksta elgtis socialiai priimtiniau, kai tuo tarpu neigiama ankstyva patirtis, emociniu santykiu trūkumas, kaip rodo mūsu tyrimo duomenys ir teigia $\mathrm{M}$. Leonard (2010), gali paskatinti polinki i netinkamas laisvalaikio veiklas. Pasak K. Samašonok ir kt. (2005), globos namu auklètiniai patiria daugiau nerimo, dažniau jaučiasi prislègti ir turi adaptacijos sunkumų, dažniau užima negatyvų statusą bendraamžiu grupejje, lyginant su gyvenančiais pilnose šeimose. Kaip parodè tyrimo rezultatai, globos institucijose neapsiribojama vien tik vaikų priežiūra. Jie skatinami dalyvauti įvairiose laisvalaikio veiklose, ir tai ugdo jų savarankiškumą, bendravimo igūdžius bei atsakomybę už savo veiksmus.

\section{IŠVADOS}

Globos namuose ir biologinėse šeimose augantys vaikai turi panašiu galimybių dalyvauti ivairiose laisvalaikio veiklose mokyklose ir kitose istaigose. Visgi daug aktyviau laisvalaikio veikloje dalyvauja biologinėse šeimose augantys vaikai. Nepriklausomai nuo socialinès aplinkos skirtumu dauguma vaikų labiausiai mėgsta sportinę veikla, kiek mažiau — muzikinę, nemažai vaikų užsiima kita menine veikla.

Biologinèse šeimose augantiems vaikams mokslai ir bendravimas su aplinkiniais sekasi geriau nei globos namuose augantiems vaikams. Dauguma biologinėse šeimose augančių vaikų ir globos namu auklètiniu geba atsispirti draugu spaudimui isitraukti i netinkamą veiklą, turi savo tvirtą nuomonę ir kiti apie tai žino, tačiau globos namų moksleiviai dažniau už šeimose augančius vaikus teigia, kad kartais atsispirti draugų spaudimui užsiimti netinkama veikla būna sunku. 


\title{
LITERATŪRA
}

Berg, K. E., Latin, R. W. (2004). Essentials of Research Methods in Health, Physical Education, Exercise Science, and Recreation. Philadelphia: Lippincott Williams And Wilkins.

Carter, M. J., Van Andel, G. E., Robb, G. M. (2003). Therapeutic Recreation, Long Grove, Illinois.

Damon, W. (2004). What is positive youth development? The Annals of the American Academy of Political and Social Science, 591, 13-24.

Fletcher, A. C, Nickerson, P., Wright, K. L. (2003). Structured leisure activities in middle childhood. Links to wellbeing, 31 (6), 553-670.

Heath, P. (2009). Parental Structuring of Children's Leisure Time Research, and Application Pearson Allyn Bacon Prentice Hall. P. 177-179. Priega internetu: http://www. education.com/reference/article/parental-structure-children-leisure-time

Ignatavičius, S., Matakaite, S., Šutininè, I., Tamošiūnas, T. (2003). Popamokines veiklos veiksmingumas. Tyrimo ataskaita. VPU Sociologinių švietimo tyrimų laboratorija. Prieiga internetu: http://www.smm.lt/svieitmo_bukle/doc.s/ tr_ataskaita_040303.doc.

Kaffemanienė, I., Tumelytė, D. (2008). Globos namų auklètiniu laisvalaikis ir popamokinis užimtumas. Jaunuju mokslininku darbai, 4 (20), 164-168.

Leonard, M. (2010). What's recreational about 'recreational rioting'? Children on the Research Article Streets in Belfast Children and Society, 24 (1).

McGill, J. (1996). Developing Leisure Identities. Toronto, Canada.

Mull, R. F., Bayless, K. G., Ross, C. M., Jamieson, L. M. (1997). Recreational Sport Management. Human Kinetics.

Rèklaitienė, D, Požėrienė, J., Ostasevičienė, V., Gaižauskienè, A. (2008). Tèvų globos netekusių asmenų gyvenimo kokybės ir pasirengimo savarankiškam gyvenimui įvertinimas: tyrimo ataskaita. Kaunas: Socialinès apsaugos ir darbo ministerija. Prieiga internetu: http://www.socmin. lt/index.php?1606775163>.

Salmon, J., Telford, A., Crawford, D. (2004). Children's Leisure Activites Study - Summary Report. Deakin University. Priega internetu: http://www.deakin.edu.au/hmnbs/ cpan/class_report-final1.pdf

Samašonok, K., Gudonis, V., Žukauskienè, R. (2005). Globos namų auklètinių adaptacijos mokykloje ypatumai. Ugdymo psichologija, 15, 7-17.

Shivers, J. S., deLisle, L. J. (1997). The Story of Leisure. Human Kinetics.

Sklar, S. L., Autry, C. E. (2008). Foundations of Therapeutic Recreation. T. Robertson, T. Long (Eds.). Human Kinetics.

Stumbo, N. J. Peterson, C. A. (2004). Therapeutic Recreation Program Design: Principles and Procedures. San Francisko: Pearson.

Witt, P. A., Caldwell, L. (2005). Principles of youth development. In P. A. Witt and L. L. Caldwell, Recreation and Youth Development. State College, PA: Venture.

Žalimienè, L. (2005). Children guardianship system and its trends in Lithuania. Situation review based on research results. In Every Child Counts. Vilnius: Institute for Social Research. P. 18-28.

Žalimienè, L., Skučienè, D., Lazutka, R. (2005). Vaiku socialinès globos standartų projekto taikymo galimybès. Vertinimo kriterijai bei klausimynai: ataskaita. Vilnius: Socialinès apsaugos ir darbo ministerija. Priega internetu: http://www.socmin.lt/index.php?1606775163>

Žalimienè, L. (2005). Vaiku globos sistema ir jos tendencijos Lietuvoje. Situacijos apžvalga remiantis atliktu tyrimų rezultatais. Kn. Svarbus kiekvienas vaikas. Vilnius, Socialiniu tyrimų institutas: Firidas. P. 15-27.

\section{ACTIVE LEISURE ACTIVITIES FOR CHILDREN LIVING IN BIOLOGICAL FAMILIES AND RESIDENTIAL CARE INSTITUTIONS}

\author{
Diana Rèklaitienė, Jūratė Požerienė, Vida Ostasevičienė, Aida Gaižauskienė \\ Lithuanian Academy of Physical Education, Kaunas, Lithuania
}

\begin{abstract}
Leisure time is the social area where the basic relationship could be developed, strengthened and expressed. Due to this our leisure time is deeply connected to our values, life priorities and has essential influence on the relationship in the family and society. Recently a lot of attention has been paid towards social integration of young people after leaving foster homes. The main task of the social system is to ensure qualitative leisure time in order to educate universal personality to help them integrate into the society. A lot of studies analyzing integration problems of such children, their preparation for self-supported life, social skills have been carried out. The main problems were emphasised: self-sufficient and independent life for young people leaving institutional care begins overnight - because they have to leave the care institution
\end{abstract}


just when they are 18, they do not have time to consolidate their daily skills, as the institutional conditions are not suitable for that. Studies show that these children are a vulnerable social group and they are more inclined to precarious behaviour. It should be stressed that there is lack of research concerning the actual situation and the possibilities of active leisure activities for children living in foster homes.

The aim of the research was to explore the main leisure activities for children living in biological families and foster homes. Research tasks: to find out the possibilities of active leisure activities for children living in residential care institutions and their peers living in biological families; to explore children's attitudes towards socially unaccepted activities and misbehaviour; to compare the research results between children living in residential care institutions and their peers living in biological families. The organization and methods of the research: the study involved 716 12-19-year-old children living in residential care institutions and 908 children living in their biological families. The questionaire method was used. The study results were processed with the help of the statistical package for social studies (science). The results indicated that children in institutional care had almost the same possibilities for their leisure activities in different institutions as well as children living in biological families. Still children living in biological families were more active during their leisure time. All the children were mostly involved in sports, less - in music and other activities. Children living in their biological families pointed out that they were more advanced in studies and communication skills. Children in foster homes were more advanced in singing. Children living in their biological families told that they could resist friends' pressure to be involved in unaccepted behaviour, have their own strong opinion. Children in institutional care told that sometimes it was hard for them to resist friends' pressure to be involved in unaccepted behaviour.

Keywords: leisure activities, biological families, residential care institutions, precarious behaviour. 